\title{
POCZĄTKI BIBLIOTEKI KONWENTU KRAKOWSKIEGO POD WEZWANIEM ŚW. BERNARDYNA ZE SIENY
}

UWAGI WSTEPNE

Zamiłowanie do korzystania z książek i bibliotek w Zakonie Braci Mniejszych już od początku jego istnienia w wieku XIII wzmogło się szczególnie w konwentach miast uniwersyteckich, wśród braci studiujących i profesorów wydziałów teologicznych i sztuk wyzwolonych oraz lektorów studiów generalnych i prowincjalnych zakonu. Także w konwentach nie zwiazzanychi $z$ wyższym szkolnictwem, ani z zakonnymi studiami przygotowującymi do kapłaństwa, tworzono księgozbiory pod kątem wykorzystania ich w działalności duszpasterskiej, a najbardziej w kaznodziejskiej. Utarła się z czasem praktyka, że kaznodzieja klasztorny był równocześnie bibliotekarzem, a jego mieszkanie, jakby filią biblioteki, gdyż wystarczyła zgoda przełożonego i wpis na poczatku ksiażki: „dla mieszkania kaznodziei" (pro cella praedicatoris), by dane dzieła mogły być przechowywane w jego mieszkaniu przez dhugie miesiące, a nawet lata, jako jego podręczny księgozbiór. Co więcej zgodnie z Regułą św. Franciszka o zakazie jazdy konnej, w przypadku pieszych podróży kaznodziejów na kapituły prowincjalne lub inne prace apostolskie, przełożeni mieli obowiązek wysłać za nimi potrzebne księgi, korzystając z pomocy ludzi świeckich, zapewne klasztornych syndyków lub członków trzeciego zakonu".

Żaden zakonnik nie mógł posiadać książek na własność, ale mógł z nich korzystać na zasadzie wypożyczenia z biblioteki konwenckiej. Utarła się praktyka, iż podobnie jak kaznodzieja i zarazem bibliotekarz, również przełożeni i wikariusze konwentu mogli trzymać u siebie potrzebne kodeksy, zamieszczając notkę proweniencyjna, np. „dla celi przełożonego" (pro cella praepositi) ${ }^{2}$. Dotyczyło to również zakonników nie pełniących żadnych urzędów, ale wyróżniających się praca naukowa, pisarstwem teologiczno-filozoficznym i historycznym lub przepisywaniem ksiag. Konwent krakowski św. Bernardyna ze Sieny był szczególnym centrum tego rodzaju prac w prowincji zakonnej, $\mathrm{z}$ siedzibą w stołecznym Kra-

${ }^{1}$ Uchwała kapituły prowincjalnej w Przeworsku w 1539 r. - Bibl. Czartoryskich w Krakowie Rkp. XVII/2469: Anagriphe II, s. $395 \mathrm{nr} 5$.

${ }^{2}$ K. K a n t a k, Bernardyni polscy, t. 1. Lwów 1933, s. 310. 
kowie. Od powstania pierwszych klasztorów bernardyńskich w latach 50-tych i następnych wieku XV, konwent św. Bernardyna w stolicy kraju był największy i najlepiej obsadzony. Posiadał najliczniejszy zakonnej nowicjat, a także studium przygotowujące do kapłaństwa. Przy pierwszej bibliotece i archiwum prosperowało na stosunkowo wysokim poziomie skryptorium klasztorne. Żaden inny konwent w prowincji nie wydawał tak wielkiej ilości publikacji i nie miał tylu pisarzy. Zdaniem K. Kantaka w podwawelskim konwencie powstały takie dzieła literatury jak: „Legenda św. Stanisława” autorstwa bernardyńskiego pisarza, mistrza Stanisława, a także dzieło byłego profesora Akademii Krakowskiej, Stanisława ze Stobnicy pt. „Mowa skrócona” (Breviloquium); następnie pierwszy w Polsce „Opis Jerozolimy” Anzelma zwanego Polakiem, oraz pierwsza kronika bernardynów w Polsce Jana z Komorowa pt. „Pamiątka Zakonu Braci Mniejszych" (Memoriale Ordinis Fratrum Minorum).

Zakonni pisarze mieszkający w krakowskim konwencie mieli szczególne prawa do korzystania z miejscowej biblioteki i archiwum. Podobnie jak kaznodzieje i przełożeni, mieli przywilej wypożyczania i przetrzymywania w swoich mieszkaniach ksiagg z biblioteki i akt archiwalnych. O ile zaś pewne kodeksy były nabyte przez nich osobiście, jak to miało miejsce w przypadku Klemensa Ramułta z Radymna ${ }^{4}$, to zapewne mogli je przechowywać w podręcznych księgozbiorach aż do końca życia.

\section{PRAWO ZAKONNE A BIBLIOTEKI \\ (ZARYS PROBLEMU)}

Prawodawstwo zakonne zatwierdzone przez Stolice Apostolską stopniowo ujęło praktykę organizowania bibliotek konwenckich i korzystania $\mathrm{z}$ nich, w osobne normy, co dało podstawy niektórym większym bibliotekom do tworzenia własnych regulaminów. Ta gorliwość w organizowaniu dobrze prosperujących księgozbiorów klasztornych i zaopatrywaniu ich w coraz to nowe kodeksy pergaminowe i papierowe przeszła u schyłku średniowiecza, w wieku XV także na braci reformy obserwanckiej ${ }^{5}$. Wprawdzie pierwsze klasztory tej reformy zakładane przez św. Jana Kapistrana w Europie środkowej i wschodniej, a w tym i w Polsce nie wykazywały początkowo większego zainteresowania w tworzeniu bibliotek, a nawet $\mathrm{w}$ imię ubóstwa były im niekiedy przeciwne, to jednak zdaniem Hofera nie miało to większego uzasadnienia ${ }^{6}$, gdyż św. Jan Kapistran, jako przywódca obserwancji i jej szerzyciel w krajach Rzeszy niemieckiej i Europy wschodniej, sam przejął najlepsze tradycje zakonu i wykazywał duże zainteresowanie cennymi dziełami teologicznymi i przy nadarzającej się okazji wysyłał

\footnotetext{
${ }^{3}$ Tamże, s. 77.

${ }^{4}$ W. F. M u r a w i e c, Ramult Klemens z Radymna (zm. 1587). W: PSB, t. 30: 1987, s. 552.

${ }^{5}$ J. H o fer, Johannes Kapistran. Ein Leben im Kampf um die Reform der Kirche. Heidelberg-Romae, s. 430.

6 Tamże.
} 
szereg ofiarowanych sobie dzieł z Niemiec do macierzystej prowincji zakonnej we Włoszech?

W napisanych przez niego konstytucjach z 1443 roku, które następnie obowiązywały w klasztorach obserwanckich $\mathrm{w}$ familii cismontańskiej, a więc i w Polsce, nie było wprawdzie wzmianki o bibliotekach, to jednak nie wprost, przy interpretacji rozdziału 5. Reguły św. Franciszka „O potrzebie pracowania"8 został położony nacisk na tworzenie i rozwój studiów wewnętrznych (studia et lectiones) ${ }^{9}$, a więc również całego ich zaplecza. Świadczy o tym zresztą wspomniana praktyka Jana Kapistrana, polegająca na rozdzielaniu klasztorom książek, które ze sobą woził. Świadczy o tym również dokument papieski wydany na jego prośbę w 1448 r., który zabezpieczał w czasie jego podróży, wszystkie przewożone kodeksy oraz inne rzeczy codziennego użytku, szczególnie związane $\mathrm{z}$ codziennym odprawianiem Mszy św. i pracą kaznodziejską ${ }^{10}$.

\section{ŚW. JAN KAPISTRAN I INNI OFIARODAWCY KODEKSÓW}

Początki księgozbioru, a następnie biblioteki konwentu bernardynów w Krakowie na Stradomiu sięgają lat 50-tych XV w., kiedy to założyciel tegoż konwentu św. Jan Kapistran tuż przed swoją śmiercią (+1456) przekazał na ręce polskich braci z Krakowa kilka traktatów prawno-teologicznych i ascetycznych własnego autorstwa, w postaci książek rękopiśmiennych: o prymacie papieża i jego wyższości nad soborem powszechnym, o walce duchowej wiernych, o czasach ostatecznych, o potędze antychrysta i o końcu świata ${ }^{11}$. Sądząc po opisie zewnętrznym jednej z tych pozycji autorstwa Kapistrana, jego kazania o Męce Pańskiej, spisanego i oprawionego w małym formacie (libellus), które później

${ }^{7}$ Tamże.

${ }^{8}$ W „Regule” św. Franciszka z Asyżu z 1223 r, nie ma wprawdzie mowy o bibliotekach, ani o korzystaniu z książek przez zakonników, poza wzmianką o prawie do posiadania przez nich brewiarzy, jednak pod warunkiem, że umieją czytać: „Klerycy niech odmawiaja Boskie oficjum ... dlatego mogą mieć brewiarze". - Reguta św. Franciszka z Asyżu z 1223 r. W: Pisma św. Franciszka z Asyżu. Przeł. K. Ambrożkiewicz OFM Cap. Warszawa 1976, s. 85; K. Ś 1 a s k a, Funkcja ksiażki w zakonie bernardynów w XVII w. W: Z badań nad polskimi księgozbiorami historycznymi. Pod red. B. Bieńkowskiej. Warszawa 1992, s. 132.

${ }_{9}$ Joannes Capistranus, Ordinationes Eugenianae super Regulam Fratrum Minorum, sub Eugenio IV (1443). W: Opera omnia Joannis a Capistrano /Facsimille della "Collectione Aracoelitana" reddata da p. Antonio Sessa da Palermo/. T. V. 2. L'Aquila 1985, s. 33/III.

${ }^{10}$ Pap. Mikołaj III wydał list bezpieczeństwa (salvum conductum) dla św. Jana Kapistrana, na przewóz rzeczy codziennego użytku oraz książek, zaczynający się od słów: „Cum dilectus filius Joannes...". Bullarium Franciscanum. Nova series, T. 1. 1431 1455. Ed. U. Hüntemann OFM. Quaracchi /Ad Claras Aquas/ 1929, s. 619 nr 1213.

${ }^{11}$ L. W a d d ing OFM, Annales Minorum. T. 12. Quaracchi 1932, s. $484 / 420 / \mathrm{nr} 125$. Oryginalne tytuły tych książek darowanych przez św. Jana Kapistrana były następujące: 1. Tractatus de Papae et Concilii authoritate; 2. De bello spirituali temporis Antichristi (Jest to trzeci rozdzial szerszego opracowania pt. „De iuditio spirituali in futuro et Antichristo"); 3. De Antichristo et eius temporibus (Jest to częsć druga wspomnianego traktatu "De iuditio universali..."). - Por. Opera omnia s. Joannis Capistrani. Wyd. Antonio Sessa OFM de Palermo. Vol. 3. I - 2. L'Aquila 1985, ss. 1-539; vol. 13. IV - 2. L'Aquila, s. 1-345. 
konwent krakowski podarował bibliotece klasztoru w Samborze (ok. 1460), jak również po jego nocie własnościowej cytowanej przez Łukasza Waddinga, były to książki pisane ręcznie na pergaminie, średniego formatu. Jest to zrozumiałe ze względu na odległości, które Kapistran musiał pokonywać i uciążliwość ówczesnej komunikacji. Zresztą w przekazie „Roczników” Waddinga mamy informację, że „ojcowie polscy troskliwie strzegli pewne jego niewielkie dziełka (opuscula)", co wskazuje właśnie na małe lub średnie formaty. Nic też nie wiemy, czy były to teksty iluminowane, czy tylko spisane gotyckim pismem na pergaminie, oprawne w deskę powleczoną skórą z podwójnymi klamerkami.

Do pozycji teologicznych i ascetycznych ofiarowanych przez Jana Kapistrana doszły kolejne książki rękopiśmienne, pochodzące $\mathrm{z}$ darów ludzi, w jakiś sposób związanych z bernardynami krakowskimi, m.in. „Concordantiae numerales"12 ofiarowane w czasie pobytu Kapistrana w Krakowie, przez profesora Akademii Krakowskiej Andrzeja Grzymałę ${ }^{13}$. Była to konkordancja biblijna Starego i Nowego Testamentu, służąca kaznodziejom, lektorom i pisarzom teologicznym do wyszukiwania właściwych cytatów Pisma św. na określony temat.

Wśród ofiarodawców z grona profesorskiego Akademii Krakowskiej, którzy złożyli swoje dary w postaci książek rękopiśmiennych i drukowanych, należeli w drugiej połowie XV i na początku wieku XVI: Marcin Biem (zm. 1540), Jakub Friedl z Kleparza (ur. 1484), Jan z Sanoka (ur. 1480), Grzegorz ze Stawiszyna (ur. 1481), Marcin Kołeczek (2 poł. XV w.) i Jan Rosiński (2 poł. XV w.)14. Czy fundator klasztoru, kardynał Zbigniew Oleśnicki oraz jego brat Jan przekazali jakieś książki z tytułu fundacji, jak to uczynili fundatorzy klasztoru w Tykocinie (1479), w Skępem (1498) i w Kazimierzu (1514) ${ }^{15}$, nie można wykluczyć odpowiedzi twierdzącej, choć nie ma na to bezpośrednich dowodów. Wykonawca testamentu Oleśnickiego, historyk Jan Długosz, który dopilnował budowy prezbiterium kościoła św. Bernardyna w Krakowie, po śmierci kardynała - fundatora ograniczył się zapewne tylko do wiernego wykonania jego woli.

${ }^{12}$ Obecnie w Bibliotece Jagiellońskiej pod sygn. AA XI 6. - Por. W. W i s ł o c k i, Katalog rękopisów BJ. Kraków 1877/81 nr 2812; K. K a n t a k, Bernardyni ..., t. 1, s. 308.

${ }^{13}$ Andrzej Grzymała z Poznania (zm. 1466) był profesorem i dwukrotnie rektorem Akademii Krakowskiej. W latach 50. XV w., podczas głośnych wystappień w Krakowie kaznodziei św. Jana Kapistrana, Grzymała występuje jako „collega maior”, a następnie jako prepozyt tegoż Kolegium (1454). Należał do zapoczątkowanej przez Marcina Króla z Żurawicy, krakowskiej szkoły matematycznej i astronomicznej. Podczas swojego pobytu w Italii (1461) doktoryzował się w zakresie medycyny na Uniwersytecie w Peruggi, a po powrocie do Krakowa studiował też prawo kanoniczne i uzyskal prawny licencjat. Zmarł w Krakowie w 1466 r. - Aleksander B i r k e n m a j e r, Grzymata Andrzej z Poznania. W: PSB, t. 9:1969-1961, s. 114-116; tenże, Andrzej Grzymała z Poznania, astronom i lekarz z XV wieku. „Kwartalnik Historii Nauki i Techniki”. 3: 1958, s. 409, 422; P. R y b i c k i, Odrodzenie. W: Historia nauki polskiej. T. 1. Pod red. B. Suchodolskiego. Wr.-W-Kr. 1970, s. 101, 106, 283; I. Z a r ę b s k i, Okres wczesnego humanizmu. W: Dzieje Uniwersytetu Jagiellońskiego w latach 1364-1764. T. 1. Pod red. K. Lepszego. Kraków 1964, s. 180-183.

${ }^{14}$ E. L e n a $\mathrm{t}$ OFM, Przedtrydenckie rekkopisy liturgiczne w Bibliotece Prowincji oo. Bernardynów w Krakowie. Studium źródtoznawczo-liturgiczne. „Archiwa, Biblioteki i Muzea Kościelne". T. 48: 1984, s. /11/ 143; K. K a n t a k, Bernardyni..., t. 1, s. 243, 245.

${ }^{15}$ W. F. M u raw i c c OFM, Ramutt Klemens z Radymna. W: PSB, t. 30: 1987, s. 552. 


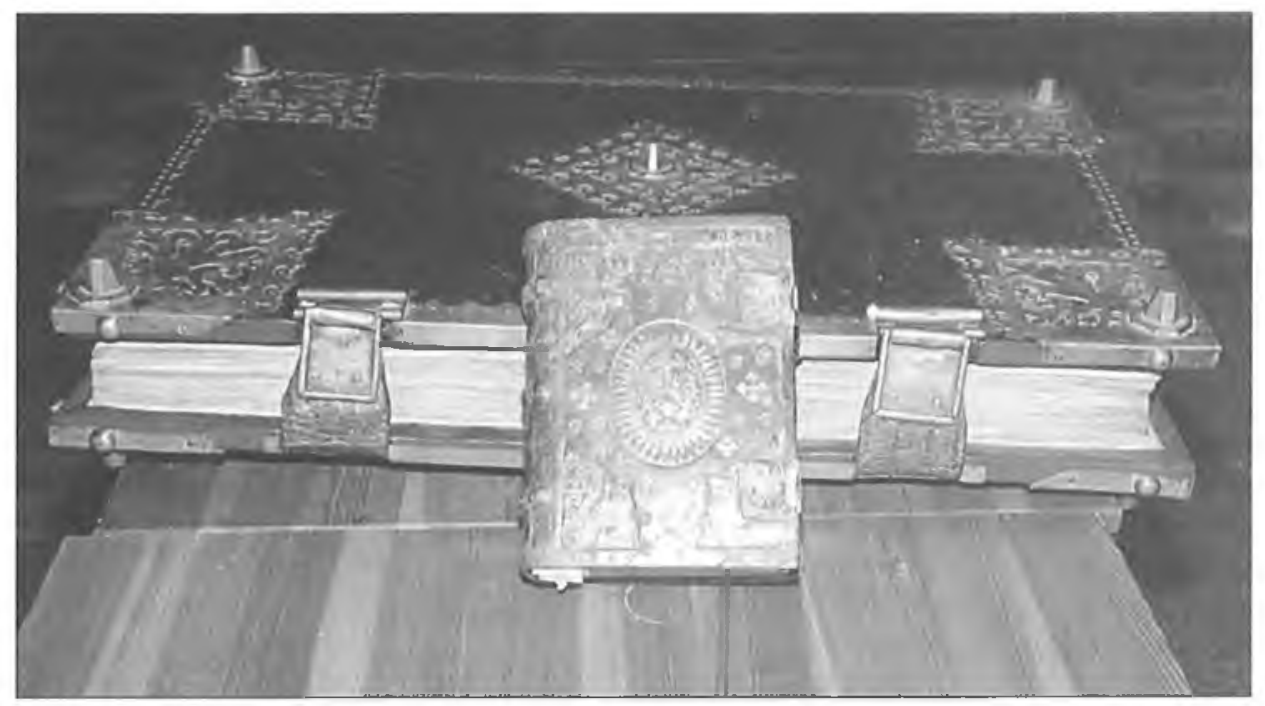

1. Tzw. Kodeks bł. Szymona z Lipnicy z 2 poł. XV w. (Biblioteka Prowincji oo. Bernardynów, sygn. 1/R).

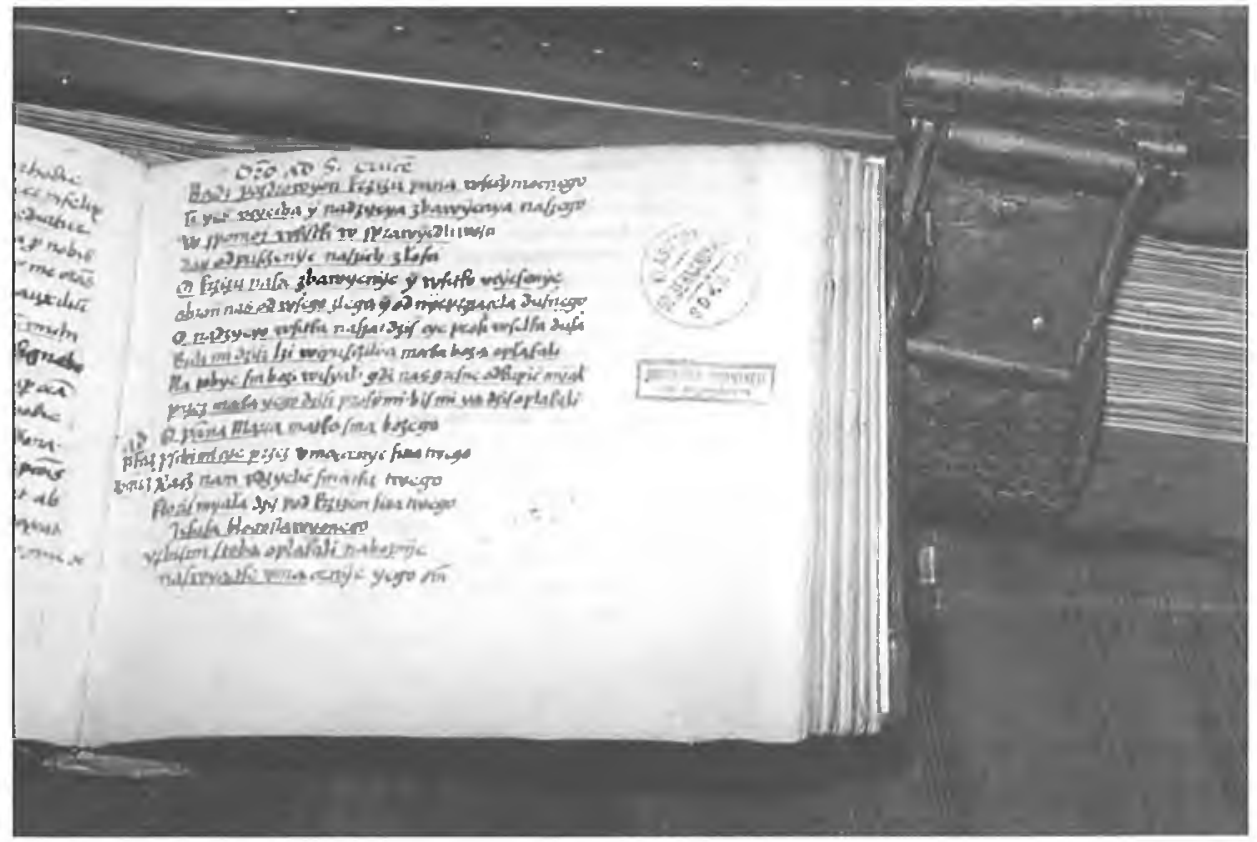

2. Rękopis bł. Władysława z Gielniowa. (Staropolski tekst pieśni o Krzyżu Świętym BPBK sygn. 3/R). 


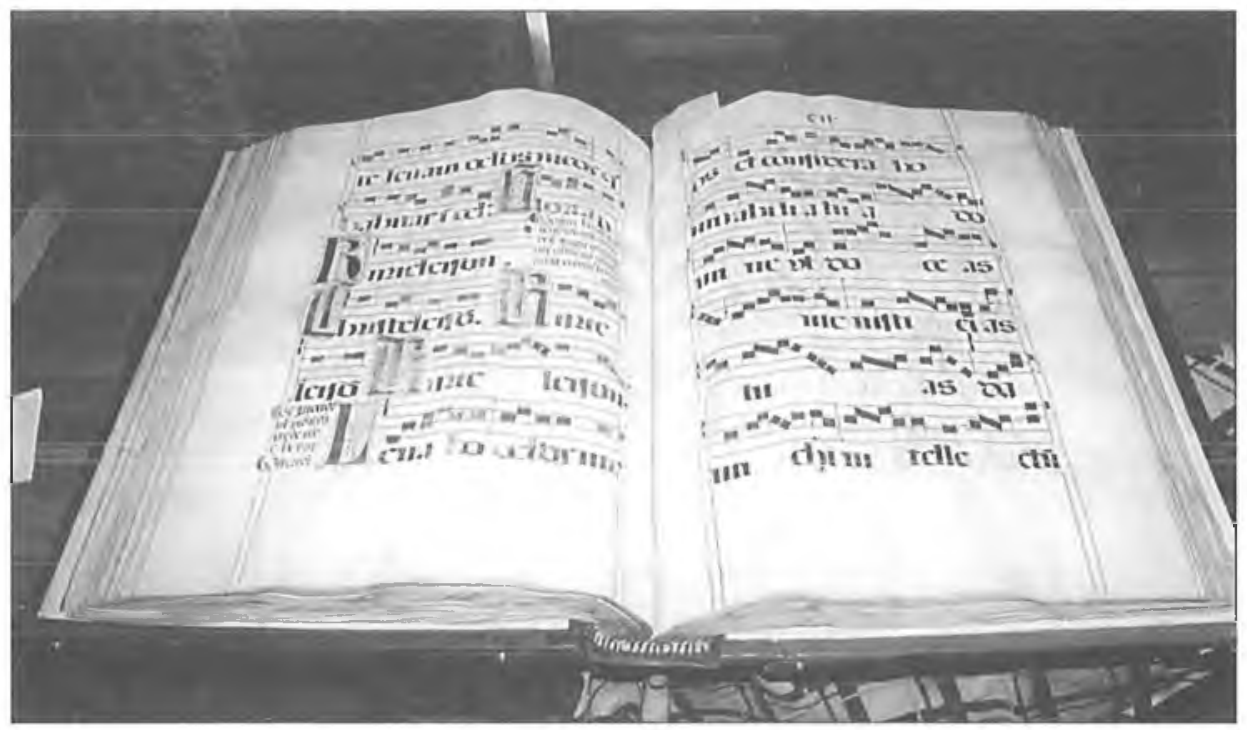

3. Graduał z pierwszej połowy XVI w. (Bibl. Prow. oo. Bernardynów, sygn. 10/RL).

4. Pawła Diakona „Homiliarius Doctorum" (napisany w 799 r.). BPBK sygn. XV 516.

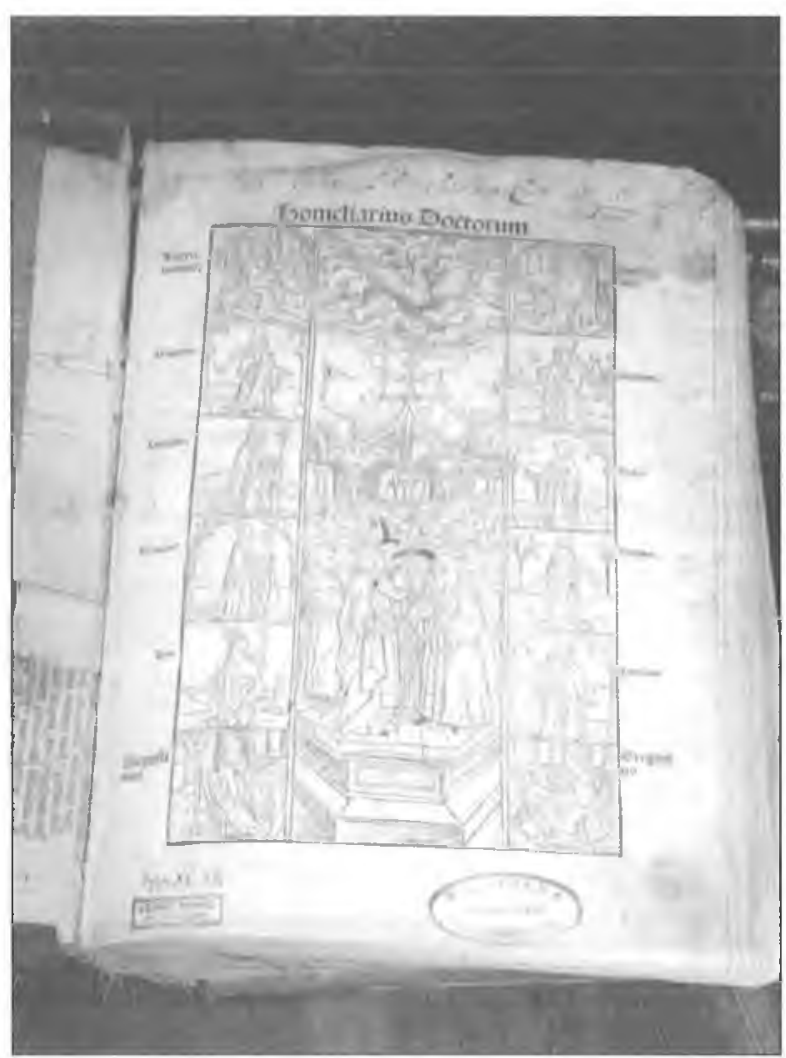


Początkowy dystans pierwszych obserwantów w klasztorze podwawelskim w stosunku do książek i bibliotek przejawiał się $\mathrm{m}$. in. w tym, że stosunkowo liczne wstępowanie do ich konwentu mistrzów, bakałarzy i studentów, a niekiedy i profesorów Akademii Krakowskiej łączono z całkowitym zerwaniem z pracą wykonywaną wcześniej. Przykład stanowił Jan Szklarek z Trzemeśni k. Myślenic, profesor Akademii Krakowskiej, który wstapił do klasztoru pod Wawelem ok. $1481 \mathrm{r}$. i wygłosił swój ostatni wykład $z$ mnemotechniki, w kościele św. Bernardyna, stanowiący swego rodzaju pożegnanie $\mathrm{z}$ uczelnia ${ }^{16}$. Zapewne $\mathrm{i}$ inni profesorowie i docenci w podobny sposób żegnali się z kolegami i studentami przed wstappieniem do klasztoru. Zaczynali bowiem nowe życie ukierunkowane na ascezę i działalność duszpasterska, czego wstępnym warunkiem było zerwanie $\mathrm{z}$ dotychczasowym środowiskiem społecznym i naukowym. Stąd nie należy się dziwić, iż w początkowym okresie, w drugiej połowie XV i na początku XVI wieku nie nabywano książek do biblioteki klasztornej w drodze zamiany lub kupna, a poprzestawano tylko na kodeksach pochodzących $\mathrm{z}$ daró $\mathrm{w}^{17}$, $\mathrm{z}$ produkcji własnych przepisywaczy $\mathrm{w}$ skryptoriach, a z biegiem czasu także z krakowskich drukarni.

\section{INNE SPOSOBY UZUPEENIANIA KSIEGOZBIORU KLASZTORNEGO}

Podobnie jak w klasztorach zachodniej Europy, również w Polsce jednym ze sposobów wzbogacania biblioteki były księgozbiory po zmarłych braciach. Prawo dysponowania nimi miał tylko prowincjał, który powinien był nakazać włączyć je do miejscowej biblioteki klasztornej dla wspólnoty zakonnej. Było to wcześniejsze prawo ogólnozakonne, powtórzone częściowo na kapitule prowincji polskiej w Kaliszu, w 1546 r. i w Samborze $(1597)^{18}$. Powtórzenie to zawierało jednak znaczne złagodzenia w stosunku do konstytucji tzw. benedyktyńskich z 1336 r., które nakazywały tworzyć inwentarze bibliotek w Zakonie Braci Mniejszych, a książki po zmarłych włączać do bibliotek ich konwentów ${ }^{19}$. Prawodawstwo ogólnozakonne wyraźnie zabraniało rozdawania takich ksiażek braciom (,ne distrahantur") ${ }^{20}$, podczas gdy prawo lokalne w wieku XVI w Polsce dawało już takie możliwości prawne.

Wspomniana kapituła obradująca w Kaliszu w 1546 r. z jednej strony poszerzała władzę prowincjałów nad księgozbiorami po zmarłych, a z drugiej skłaniała gwardianów do większej troski o konwenckie księgozbiory. Dotyczyło to

${ }^{16}$ S. D o b r z a n ow sk i, Szklarek Jan z Trzemeśni. W: Stownik polskich pisarzy franciszkańskich. Pod red. H. E. Wyczawskiego. Warszawa 1981, s. 479; Biblioteka Jagiellońska Rkp. 5359 , t. 14, k. 60; Janocki, Nachricht..., t. 2, s. 84.

${ }^{17}$ K. K a n t a k, Bernardyni..., t. 1, s. 309.

18 Archiwum Prowincji oo. Bernardynow w Krakowie /APBK/, Rkp. syg. /fotocop./ nr 1: Constitutiones provinciales, 1579-1656, $\mathrm{k} 35$.

${ }_{19}$ M. B i h 1, Ordinationes a Benedicto XII editae. "Archivum Franciscanum Historicum” R. 30: 1937, s. $330 \mathrm{nr} 17$.

${ }^{20}$ Tamże. 
tak odchodzacych, jak i nowo mianowanych gwardianów, gdyż jedni i drudzy mieli obowiązek skontrolować zasób biblioteczny według rejestrów ksiąg zabranych z biblioteki, a przed kapitułą zwróconych ${ }^{21}$. Nakazywała też stworzenie katalogu („registrum”) w dwu egzemplarzach, z których jeden miał otrzymać kaznodzieja-bibliotekarz, a drugi - gwardian konwentu ${ }^{22}$. Ponadto nakazano coś w rodzaju skontrum, po odjechaniu przełożonego na kapitułę prowincjalna, by nowomianowany mógł bezpośrednio po kapitule otrzymać gotowy spis ewentualnych brakujących pozycji. Był też zakaz przetrzymywania przez kogokolwiek ksiag heretyckich bez zgody prowincjała. W zasadzie nie wolno też było wypożyczać książek z biblioteki klasztornej na zewnątrz, z wyjątkiem znaczniejszych osób, zasłużonych dla klasztoru, ale tylko za zgoda miejscowego gwardiana. Takie książki wypożyczone dobrodziejom konwentu miały być zwrócone najpóźniej przed jego wyjazdem na kapituła prowincjalna ${ }^{23}$.

Ważnym źródłem wzbogacania biblioteki klasztornej w Krakowie oraz innych bibliotek bernardyńskich w kraju, do końca XV w. i w wieku następnym, obok druków, była w dalszym ciagu własna produkcja kodeksów w zakonnych skryptoriach. Szczególnie skryptorium krakowskiego konwentu, jako najstarsze i nastawione na przepisywanie ksiag liturgicznych oraz pomocy teologicznych i kaznodziejskich dla nowopowstających klasztorów wikarii, a od 1517 roku prowincji polskiej bernardynów, stanowiło główny ośrodek wytwarzania książki rękopiśmiennej. Sądząc po zachowanych egzemplarzach przepisywano tu przede wszystkim księgi liturgiczne: psałterze i antyfoniarze shużące do odmawiania i śpiewania codziennego brewiarza, a także kancjonały i graduały zawierające śpiewy gregoriańskie hymnów i różnych wersji śpiewów mszalnych z tekstami gradualnymi włącznie ${ }^{24}$. Nie wiadomo tylko dlaczego nie zachowały się mszały rękopiśmienne. Zapewne zniszczono je po upowszechnieniu pierwszych mszałów drukowanych ${ }^{25}$.

Zachowały się stosunkowo duże zbiory ksiąg liturgicznych wykonanych w bernardyńskich skryptoriach, które od początku należały do zakonnych konwentów w Polsce i były przechowywane w specjalnych, ozdobnych skrzyniach w chórze zakonnym i w magazynach klasztornych. Rozkładano je na pulpicie chórowym w czasie śpiewów mszalnych, podczas nocnej jutrzni brewiarzowej oraz innych godzin świętego Oficjum (brewiarza), odmawianych lub śpiewanych $w$ ciagu dnia ${ }^{26}$. $\mathrm{Z}$ czasem jednak, w okresie niewoli narodowej, kiedy to zaborcy zlikwidowali większość klasztorów bernardyńskich za udział w powstaniach w wieku XIX, większość ksiag liturgicznych i bibliotecznych poklasztornych

${ }^{21}$ APBK Rkp. /fotocop./ nr 1: Constitutiones ..., k 34 (art. 13).

22 Tamże.

${ }^{23}$ Tamże, k. 35.

${ }^{24}$ Barbara M i o d oń s k a, Małopolskie malarstwo ksiqżkowe, 1320-1540. Warszawa 1993, s. 147

${ }^{25}$ Tamże.

${ }^{26}$ Wykonywano je w skryptoriach klasztornych także po wynalezieniu druku, do XVIII w. i otaczano czcią niemal sakralnø nie starając się o księgi liturgiczne drukowane. - A. P a bi n OFM, Ksiqżka rękopiśmienna w środowisku bernardyńskim do połowy XVI w. W: Z badań nad polskimi księgozbiorami historycznymi. T. 4. Pod red. B. Bieńkowskiej. Warszawa 1980, s. 100. 
trafiła do zbiorów kapitulnych i bibliotek seminariów diecezjalnych oraz zbiorów państwowych. W związku z tym do chwili obecnej pobernardyńskie księgi liturgiczne są rozproszone po różnych bibliotekach kościelnych i państwowych, takich jak: Biblioteka Narodowa w Warszawie, Biblioteka XX. Czartoryskich w Krakowie, Biblioteka Wyższego Seminarium w Sandomierzu i Biblioteka Prowincji Bernardynów w Krakowie ${ }^{27}$. Wszystko to świadczy o działalności skryptoriów bernardyńskich, a szczególnie krakowskiego na szerszą skalę. Wśród wielu skryptorów z drugiej połowy XV w. i z wieku XVI ustalono 19 nazwisk ${ }^{28}$, o których wiemy, że byli przepisywaczami tych wszystkich zbiorów, ale o twórczości poszczególnych iluminatorów, malarzy, miniaturzystów i skryptorów nie można powiedzieć zbyt wiele, poza faktem ich przynależności do tej grupy wykonawców i daty śmierci, dzięki zachowanym nekrologom zakonnym. Natomiast pozostałe źródła archiwalne zupełnie o nich milczą ${ }^{29}$.

\section{SKRYPTORZY KSIAG LITURGICZNYCH}

Do czołowych i najbardziej znanych miniaturzystów i iluminatorów krakowskiego konwentu, który był zapewne kierownikiem skryptorium przez wiele lat i patronował ukształtowaniu się specyficznie bernardyńskiego warsztatu artystycznego, należał Bernardyn z Żarnowca (zm. 1482), kantor, a równocześnie skryptor i iluminator, który jak czytamy w nekrologu: „Wypełnił klasztory najlepszymi księgami chórowymi"30. Do równie czołowych skryptorów krakowskich, aczkolwiek mniej znanych, którzy pracowali pod koniec XV w. i w pierwszej połowie XVI w. i łączyli swoją pracę w skryptorium $\mathrm{z}$ innymi urzędami w konwencie, jak kaznodziejstwo, spowiedź, kantorstwo, a nawet gwardiaństwo, należeli: Seweryn Popiołek (zm. 1513), Baltazar Ptaszek (zm. 1515), Augustyn z Głogowa (zm. 1515), Celestyn z Grodziska (zm. 1519), Michał z Krosna (zm. 1520), Maciej z Tarnowa (zm. 1523) i Józef z Tyśmienicy (zm. 1543). Szczególnie o. Józef z Tyśmienicy był znany jako kontynuator Bernardyna z Żarnowca ${ }^{31}$. $\mathrm{Z}$ jego warsztatu wyszło jedno $\mathrm{z}$ ostatnich dzieł liturgicznych iluminowanych: Graduale z 1525 r., należące do konwentu krakowskiego ${ }^{32}$.

Autorów całego szeregu anonimowych ksiąg liturgicznych przechowywanych w Bibliotece Prowincji Bernardynów w Krakowie, a Bibliotece XX. Czartoryskich i Bibliotece Jagiellońskiej należy szukać wśród pracowników skryptorium klasztoru krakowskiego bernardynów lub jego filii lwowskiej, a nawet

${ }^{27}$ B. M i o do ń s k a, Matopolskie malarstwo..., s. 147.

${ }^{28}$ E. L e n a r t OFM, Przedtrydenckie rękopisy..., s. /14/ 146.

${ }^{29}$ Tamże.

30 „Multa loca Provinciae libris choralibus implevit”. - B. M i o d o ń s k a, Malarstwo matopolskie..., s. 147; K. Grudziński OFM, Bernardyn z Żarnowca. W: Stownik pracowników ksiqżki polskiej. Pod red. I. Treichel. Warszawa 1972, s. 59-60; APBK Rkp. W-20, s. 9.

${ }^{3}$ E. Le n a t $\mathrm{t}$ OFM, Przedtrydenckie rękopisy..., s. /15/ 147, /29/ 161.; K. K a n tak, J. S z a b l o w s k i, J. Ż a rn e c k i, Kościót $i$ klasztor oo. Bernardynów w Krakowie. Kraków 1938, S. $26 \mathrm{n}$.

${ }^{32}$ BPBK sygn. 1/RL passim. 
w konwentach innych części prowincji (kustodii poznańskiej, warszawskiej oraz wileńskiej). Byli to skryptorzy związani zasadniczo z określonymi klasztorami bernardyńskimi w kraju, ale nie można wykluczyć ich przejściowego, jednorazowego lub nawet kilkakrotnego pobytu w Krakowie czy we Lwowie. Podlegali bowiem w zasadzie zmianom miejsca pobytu przynajmniej co trzy lata. Wprawdzie uchwała kapituły prowincjalnej, obradującej w Poznaniu w 1478 r. zabraniała przenosić skryptorów bez ważnej przyczyny, ale tylko przed upływem trzech lat ${ }^{33}$. Przenosiny skryptorów miały miejsce $z$ różnych powodów. Jednym $\mathrm{z}$ nich była zapewne nominacja na urząd gwardiana, jak to się zdarzyło w przypadku zasłużonego skryptora, Szymona z Lipnicy w roku $1465^{34}$. A zatem anonimowe księgi liturgiczne, których autorstwa nie jesteśmy w stanie ustalić, przepisali skryptorzy znani tylko z notek nekrologowych: Bernardyn z Krakowa (zm. 1453), Jan Chryzostom z Ponieca (zm. 1478), Bernardyn z Krakowa junior (zm. 1482), Ambroży z Kłodawy (zm. 1494) ${ }^{35}$, Izaak ze Lwowa (zm. 1504).

Bernardyńscy twórcy ksiąg rękopiśmiennych, a szczególnie liturgicznych nie należeli wprawdzie do artystów najwyższej klasy w zakresie iluminacji i malarstwa miniaturowego, gdyż byli to bardzo często przypadkowi twórcy rekrutujący się spośród nowicjuszy i młodych zakonników, którzy wykonywali określone prace na zamówienie klasztorów pod okiem mistrzów i doświadczonych skryptorów, jak Bernardyn z Żarnowca, czy Józef $\mathrm{z}$ Tyśmienicy ${ }^{36}$. Oni to nadawali dziełom zasadniczy styl i zapewne je wykańczali. W związku z tym można mówić o stylistyce bernardyńskiej ksiag liturgicznych, różniącej się od wytworów skryptoriów kapitulnych oraz innych zakonów ${ }^{37}$. Dzięki szczegółowym badaniom porównawczym B. Miodońskiej dowiadujemy się, że bernardyńscy twórcy ksiąg odznaczali się dużą starannością, a wytworzony przez nich warsztat wyróżniał się prostota, „tradycjonalizmem stylowym” oraz charakterystyczną dla obserwanckich rzemieślników i artystów „oszczędnością środków artystycznego przekazu". Jest to szczególnie widoczne w miniaturowej ikonografii, gdzie np. złoto zostało użyte wyjątkowo oszczędnie. Najchętniej artysta zastępował je tempera ${ }^{38}$. Ponadto bordiurowe i wszystkie inne marginalne ozdoby kodeksów nie wychodziły poza symbolikę roślinna, akantoidealna, z wykluczeniem motywów figuralnych ${ }^{39}$. Malarstwo religijne zaprezentowane przez malarzy bernar-

${ }^{33}$ E. L e n a r t OFM, Przedtrydenckie rękopisy ..., s. /16/ 148.

${ }^{34}$ R. G u st a w OFM, K. G r u d z iń s k i OFM, Btogostawiony Szymon z Lipnicy. Kalwaria Zebrzydowska 1988, s. 31. - Szymon został przeniesiony wówczas do Tarnowa na stanowisko gwardiana tamtejszego konwentu.

${ }^{35}$ E. L e n ar $t$ OFM, Przedtrydenckie rękopisy..., s. /15/ 147.

${ }^{36}$ Ówcześni autorzy not w zakonnych księgach zmartych (nekrologach) zamieścili o poszczególnych skryptorach kodeksów rękopiśmiennych bardzo krótkie informacje dotyczące ich działalności, np. że przepisał własnoręcznie wiele mszałów, szczególnie dla klasztoru krakowskiego, „przepisat psalterze po różnych konwentach, dla wielorakiej chwaty /Bożej/" .../byt to/ „, wybitny kopista /scriptor/, który przepisat wiele ksiqg, zwłaszcza chórowych, z wielkq mitościq $i$ doktadnościq". - B. M i o d on s k a, Iluminacje graduatu bernardyńskiego fundacji Odroważów. „Rocznik Krakowski" T. 39: 1969, s. 60.

${ }^{37}$ B. M i o do ń s k a, Matopolskie malarstwo ksiaż́kowe. Warszawa 1993, s. 148.

${ }^{38}$ Tamże.

${ }^{39}$ Tamże. 
dyńskich $\mathrm{w}$ kodeksach czerpało swoje natchnienie $\mathrm{z}$ kopiowanych tekstów. W psałterzach był to naogół król Dawid, autor, jak wówczas sądzono, wszystkich psalmów. Np. w miniaturze psalmu 69: „Wybaw mnie, Boże, bo woda sięga mi po szyję"40, mamy nagiego króla Dawida w koronie, stojącego w wodzie po szyję. Bohaterami tego malarstwa bywają także inne osoby, wzięte z życia współczesnego malarzowi. Sa tu $\mathrm{m}$. in. zakonnicy w bernardyńskich habitach, modlący się z psałterza przy pulpicie, w chórze zakonnym, stanowiący ilustrację do pierwszego wersetu psalmu 117: „Chwalcie Pana wszystkie narody”. Biblijny „głupiec", ubrany jak współczesny clown cyrkowy - stanowi ilustrację do psalmu 14: "Powiedział głupi w sercu swoim: «nie ma Boga»"41.

Pozostałe księgi: gradualne, kancjonały $\mathrm{i}$ antyfoniarze w swoim malarstwie miniaturowym zamieszczają obok wspomnianej interpretacji historycznej, komentarz typologiczny tekstów, wskazujących na życie i mękę Zbawiciela, czyli na motyw zasadniczy, soteriologiczny, oraz na powiązaną z nim ściśle scenografią franciszkańską w postaci stygmatyzacji św. Franciszka oraz ukrzyżowania Chrystusa w otoczeniu św. Franciszka i Bernardyna ze Sieny ${ }^{42}$.

Najwcześniejsze kontakty krakowskich braci mniejszych "de observantia" z zakonnikami węgierskimi, zarówno przez pierwszego z nich, Władysława de Thari, Węgra, którego tu przysłał już w roku 1452 św. Jan Kapistran, a następnie $\mathrm{z}$ braćmi w Ołomuńcu. wskazują na kontakty z różnymi dzielnicami ówczesnych Węgier i z Czechami. W klasycznych kodeksach liturgicznych, iluminowanych, w Brewiarzu Fryderyka III, Mszale Jana z Bludowa (z Ołomuńca - 1469), Mszale Benedykta z Louky (Praga - 1483), jak również w innym malarstwie książkowym na Morawach i Spiszu z lat 1460-1490 stwierdzono wyraźne wpływy na warsztat iluminatorski wykonawców bernardyńskich $z$ lat 90 -tych XV w. ${ }^{43}$ Stanowiły one wzór dla iluminatorów bernardyńskich w Krakowie, względnie dla ich współbraci skryptorów w klasztorach południowych sąsiadów.

\section{BL. SZYMON Z LIPNICY}

\section{JAKO SKRYPTOR KONWENTU KRAKOWSKIEGO}

Nie wszyscy pracownicy skryptorium wykonywali prace zdobnicze do ksiąg liturgicznych. Pewna ich grupa zajmowała się przepisywaniem podręczników teologii i filozofii, dzieł ascetycznych i prawnych oraz materiałów kaznodziejskich. W Bibliotece Prowincji Bernardynów w Krakowie zachował się kodeks rękopiśmienny liczący ponad 1100 stron nazywany popularnie „Rękopisem b. Szymona z Lipnicy", pomimo że tekst przepisany przez Szymona liczy zaled-

${ }^{40} \mathrm{~W}$ obowiązującym wówczas thumaczeniu Wulgaty tekst pierwszego wiersza Ps. 69 był nieco inny niż w Biblii Tysiąclecia. Brzmiał następująco: „Wybaw mnie Boże, bo wody weszty do duszy mojej" (Libera me Deus, quia intraverunt aquae usque ad animam meam).

${ }^{41}$ Por. Biblioteka Prowincji oo. Bernardynów w Krakowie /BPBK/ rkp. 6/RL i 13/RL.

${ }^{42}$ Por. BPBK rkp. 12/RL i 15/RL.

${ }^{43}$ Dotyczy to szczególnie bernardyńskiego , Graduale de tempore et de Sanctis”, który obecnie znajduje się w Bibliotece Czartoryskich w Krakowie, pod sygn. B. Czart. 2827. - B. M i o d oń s k a, Matopolskie malarstwo..., s. 150. 
wie kilkaset stron. Faktem jest, iż kopia przepisana przez Szymona z Lipnicy zapoczątkowała kodeks. Kończąc kopiowanie wspomnianego fragmentu dzieła Doktora Serafickiego zamieścił własnoręczny podpis i datę. Łączyło się to zapewne $\mathrm{z}$ wprowadzeniem nowego skryptora, względnie całej ich grupy, być może nowicjuszy, którzy mieli w czasach naszego błogosławionego obowiązek kopiowania dzieł w skryptorium klasztornym ${ }^{44}$. Podlegający Szymonowi młodzi przepisywacze mieli zapewne obowiazek przepisywania dalszych tekstów pod okiem mistrza, potrzebnych w studium klasztornym i w kaznodziejstwie. Sądząc po stosunkowo dużej objętości kodeksu, oraz zmieniającym się co pewien czas charakterze bardzo drobnego pisma, przeważnie bez akapitów, jak również po nieukończonych w zasadzie tekstach poszczególnych dzieł, których przepisywania w wielu miejscach nie doprowadzono do końca, należy wnioskować, iż nie była to kontynuacja pracy, jak w przypadku kontynuacji współczesnych kronik klasztornych przez kronikarzy, ale było to zapewne równoczesne przepisywanie na składkach tego samego formatu tekstów różnych autorów, przez grupę kopistów. Teksty przepisane na składkach w całości lub w części, w oznaczonym czasie zbierano razem i oddawano introligatorowi do oprawy. I w ten sposób powstał kodeks liczący ponad tysiąc stron, jako rezultat pracy kilku lub kilkunastu kopistów. Nie wszyscy wywiązali się z zadania w oznaczonym terminie, ale musiano przerwać kopiowanie, gdyż wypożyczone dzieła należało zwrócić określonym bibliotekom klaszornym ${ }^{45}$. W skryptorium krakowskim na Stradomiu przepisywano wspomniane dzieła zapewne z kodeksów rękopiśmiennych, gdyż ich publikacje, jeśli nawet były już znane na Zachodzie, do Polski docierały $\mathrm{z}$ dużym opóźnieniem.

\section{ROZWÓJ BIBLIOTEKI PO WYNALEZIENIU DRUKU}

W latach 70-tych XV wieku i w następnych konwent krakowski korzystał już w znacznej mierze $\mathrm{z}$ usług pierwszych krakowskich drukarni. Ich produkcja okazała się mniej pracochłonna, obliczona na większą ilość egzemplarzy i w sumie tańsza. Było to dla zakonu duszpasterskiego, jakim byli bernardyni, bardzo dogodne, gdyż pozwalało na zaspokojenie potrzeb nie tylko własnego konwentu, ale również innych nowopowstałych na terenie Rzeczypospolitej. Do pierwszych druków w bibliotece św. Bernardyna należy zaliczyć „Almanach" na rok 1474 wydrukowany przez wędrownego drukarza niemieckiego, Kaspra Straubego w 1473 r., zapewne nakładem bernardynów stradomskich lub kogoś z nimi blisko związanego, np. dobrodzieja klasztoru należącego do trzeciego zakonu św. Franciszka $^{46}$. Ponadto fakt, iż w 1478 roku bernardyni krakowscy dysponowali więk-

${ }^{44}$ E. L e n a r t OFM, Przedtrydenckie rękopisy..., s. /14/ 146; C. B o g d a 1 s k i, Bernardyni w Polsce. T. 2. Kraków 1933, s. 14.

${ }^{45}$ Kopiowanie dzieła autora dominikańskiego Jakuba z Udine pozwala przypuszczać, iż było ono wypozyczone z biblioteki dominikanów.

${ }^{46}$ Powstanie pierwszego znanego druku w Polsce, jakim byl „Almanach" na rok 1474 wiaże się, zdaniem W. Szelińskiej, H. Szwejkowskiej i innych autorów, z nakładem klasztoru bernardy- 
szą ilością egzemplarzy druków o charakterze materiałów duszpasterskich z około 1475 r., pochodzących z drukarni krakowskiej Hohfedera, które ofiarowali współbraciom w Ołomuńcu na Morawach, świadczy o ich własnym nakładzie tych pozycji, albo jak twierdzi Kantak nakładcą był ktoś z ich kręgu, np. tercjarze lub członkowie bractwa przyklasztornego ${ }^{47}$.

W pierwszej połowie wieku reformacji nabywano książki do biblioteki klasztornej także utartym sposobem mendykantów, żebrząc i kwestując u możnych dobrodziejów. Tak przynajmniej zdobywał cenne kodeksy czołowy kaznodzieja bernardyński i znany polemista, Klemens Ramułt z Radymna ${ }^{48}$. Wypraszał u dobrodziejów ofiary pieniężne na kupno potrzebnych dzieł w działalności kaznodziejskiej, względnie dary w postaci kodeksów kaznodziejskich i teologicznych. O książki dla biblioteki konwenckiej w Krakowie starał się również Feliks z Kościana ${ }^{49}$.

Dalszy rozwój biblioteki miał ścisły związek z odnowieniem studiów zakonnych w drugiej połowie XVI wieku, dokonanym po kryzysie poprzedniego okresu, przez Hannibala Rossellego z Neapolu, na kapitule prowincjalnej w klasztorze św. Anny w Warszawie w 1585 r. Sam Rosselli przekazał wówczas dla biblioteki konwentu w Krakowie swoje wielotomowe dzieło pt. „Pymander”, opublikowane dzięki wsparciu finansowemu króla Stefana Batorego, prymasa Stanisława Karnkowskiego oraz swojego przyjaciela, kanonika krakowskiego, Hieronima Powodowskiego. Ocalał wprawdzie w księgozbiorze krakowskim tylko tom dziewiąty dzieła, w dwu egzemplarzach ${ }^{50}$.

W dziewięć lat po wspomnianej kapitule, trwała nadal kontynuacja wdrażania reformy studium teologii i filozofii oraz zwiazzana z nią centralizacja w konwentach studiów, dzieł potrzebnych lektorom ${ }^{51}$. W konwencie krakowskim znajdowało się wówczas studium teologii, w zwiazku z czym tutejsza biblioteka otrzymała zapewne szereg dzieł. Nie wiadomo tylko w jakiej mierze wspomniana uchwała została wprowadzona w życie. Nie ulega wszakże watpliwości, iż o wiele bardziej niż w poprzednim okresie prowincjałowie i delegaci wyjeżdżający na kapituły generalne do Włoch i Hiszpanii, pamiętali o potrzebie zaopatrywania klasztorów studyjnych w dzieła teologiczne wydawane na zachodzie Europy.

nów krakowskich. - Por. K. Ś l a s k a, Funkcja ksiqżki..., s. 132; H. S z w e j k ow s k a, Ksiqżka drukowana $w X V-X V I I I$ w. Warszawa 1983, s. 45; W. Sze 1 ińs ka, Drukarstwo krakowskie. Kraków 1974, s. 9.

${ }^{47}$ K. K a n t a k, Bernardyni..., t. 1, s. 308. - Ks. Kantak dopuszcza również możliwość, iż bernardyni otrzymali pewną ilość nie wyprzedanych egzemplarzy przy likwidacji drukarni Hochfedera.

${ }^{48}$ W. F. M u r a w i e c OFM, Ramutt Klemens z Radymna. W: PSB, t. 30: 1987, s. 552.

${ }^{49}$ E. L e n a r t OFM, Przedtrydenckie rękopisy ..., s. /11/ 143; K. K a n t a k, Bernardyni..., t. 1, s. $243,245$.

${ }^{50}$ Drugi egzemplarz „Pymandra” Rossellego otrzymał od autora nieznany z nazwiska jego spowiednik bernardyn krakowski Jakub. - H. Rosselli OFM, /Prymander Mercurii Trismegisti.../. T. 9. De septem Sacramentis. Posnaniae 1589, s. 3 (k. tyt.) /BPBK: Dział starodruków Bernardiniana, sygn. XVI b3 - Na karcie tytułowej jest tu własnoręczna dedykacja autora: „Ad usum patris Jacobi mei confessoris dedi ego frater Hannibal, ut oret pro me"\%

${ }^{51}$ Mówi o tym uchwała kapituły w Kazimierzu n. Wisłą w 1594 r. - K. K a n t a k, Bernardyni..., t. 2, s. 300; B. Czart. Rkp. XVII/2637 s. 125. 
W uchwale kapitulnej z 1597 r. chodziło przede wszystkim o zasilanie bibliotek klasttorów studyjnych książkami aktualnie potrzebnymi lektorom $\mathrm{z}$ niektórych dyscyplin teologii i filozofii oraz innych specjalności. Chodziło szczególnie o podręczniki teologii spekulatywnej, prawa kanonicznego, historii Kościoła, a także dialektyki i retoryki. Nabywały je poszczególne klasztory najczęściej na zasadzie darowizn, a niekiedy i kupna. W zwiazku z tym istniała dodatkowa instrukcja, dołączona do uchwały kazimierskiej kapituły z 1597 r., by otrzymanych w ten sposób książek nie włączać do księgozbiorów klasztornych, ale składać osobno i przy nadarzającej się okazji przesłać do konwentów studyjnych ${ }^{52}$.

Biblioteka konwentu krakowskiego, do której z biegiem czasu włączono także pozycje księgozbioru studium teologii, miała szanse na uzupełnienie ksiąg z wymienionych specjalności. Dawała ją uchwała kapituły w Kazimierzu (1597). Nad jej wprowadzaniem w życie czuwał wyznaczony zakonnik, który wyszukiwał tego rodzaju książki, umieszczając noty własnościowe miejsca przeznaczenia, czyli studium teologii lub filozofii ${ }^{53}$.

Pierwszedruki w ksiegozbiorze krakowskim wed $\nmid$ ug tradycyjn y ch dzi ałó w (pozycje wybrane):

Pismo święte; konkordancje; komentarze biblijne.

Księgi Pisma św., szczególnie Nowego Testamentu stanowiły podstawę działalności duszpasterskiej oraz pisarskiej klasztorów w zakresie teologii dogmatycznej, moralnej oraz teologii życia wewnętrznego, określanej wówczas jako ascetyka, a także innych dyscyplin wykładanych przez lektorów w studiach zakonnych. Stąd zapotrzebowanie na teksty biblijne oraz ich dobre rozumienie przez kaznodziejów, spowiedników i polemistów dawało impuls do tworzenia licznych komentarzy (cammentarii, enarrationes, quaestiones controversae), postylli i konkordancji biblijnych.

Wśród wielu wydań Biblii Starego i Nowego Testamentu, z których najwcześniejsze znalazły się w bibliotece konwentu krakowskiego należy wymienić Biblię tłoczoną w Bazylei, w oficynie Bernarda Richela w 1474 r. z dodatkami skryptora, Menarda mnicha ${ }^{54}$. Została wydana in folio, w objętości 860 stron. W kolejności chronologicznej drugie miejsce w tym dziale zajmuje potężny objętościowo kodeks, obejmujący „Psałterz” wraz z teologiczną "Glossą" Piotra Lombarda, wydrukowany w oficynie Jana Sensenmidta w Norymberdze w 1475/76 roku ${ }^{55}$. Magister „Sentencji” zaczerpnął swój komentarz z pism ojców Kościoła i pisarzy: Grzegorza Wielkiego, Hieronima, Ambrożego, Kasjodora, Alkuina, Remigiusza, Orygenesa, Izydora z Sewilli i Hilarego z Poitiers. Zaznaczono konsekwentnie ich imiona w górnej części każdej karty. Księga posiada wiele rękopiśmiennych not marginalnych, zapisanych przez czytelnika względnie

${ }^{52}$ B. Czart. Rkp. XVII/2469: Anagriphe II, s. 284 nr 1.

${ }^{53}$ Tamże, s. $394 \mathrm{nr} 3$.

${ }^{54}$ Biblia cum additionibus Menardi Monachi. Basileae 1474. - Biblioteka Prowincji oo. Bernardynów w Krakowie. Dział Inkunabułów sygn. 622; Incunabula Poloniae nr 989.

${ }^{55} \mathrm{P}$. L o m b a r d u s, Glossa marginalis Psalterii. Nürnberg 1475/6. - Incunabula Poloniae nr 4329 (Kraków Bern.). 
lektora teologii z wieku XV. Tym samym charakterem pisma oznaczono również numery psalmów.

Następnie dwa wydania strasburskie, Jana Grüningera ${ }^{56}$ z 1483 i 1492 r. Pierwsze z defektem pierwszych ksiag Starego Testamentu, natomiast drugie, wyłącznie księgi Starego Testamentu, posiada dołączony na końcu słownik nazw hebrajskich (104 stron) wraz z dołączoną postyllą literalną Mikołaja z Liry, franciszkanina, uznanego za najlepszego egzegetę średniowiecza. Jego „Postilla litteralis” była w średniowieczu niezwykle popularna i miała do 1450 r. aż 700 egzemplarzy kopii rękopiśmiennych, a od końca XV do połowy wieku XVI 100 wydań drukowanych. Wydania strasburskie Biblii z Postyllą Mikołaja z Liry z 1472 i 1497 r. należące do biblioteki bernardynów Krakowie zostały zaopatrzone uwagami krytycznymi Pawła z Burgos oraz repliką na ten atak, Jana Doeringa ${ }^{57}$. Następne trzy części, choć nie kolejne $(2,4,7)$ Postylli Hugona a S. Caro, osnutej na kanwie tekstu Psalmów (w cz. 2) oraz ksiąg: Izajasza, Jeremiasza i Barucha (w cz. 4), a także Listów św. Pawła, Jakuba, Piotra, Jana, Judy, Księgi Apokalipsy (cz. 7) ${ }^{58}$, opublikowane w Bazylei na przełomie XV i XVI wieku. Ostatnia (cz. 7) tłoczona w drukarni Jana Amerbacha około 1502 r. Wszystkie stanowiły nabytek z początku wieku XVI. Autor Postylli, kardynał Hugo, doradca papieży, a przy tym teolog, biblista paryski zamieścił obok tekstu własnego autorstwa, także prologi, $m$. in. św. Hieronima, do niektórych ksiag świętych, oraz prolog przed rozważaniem księgi Apokalipsy, autorstwa franciszkańskiego teologa, z kregu starszej szkoły franciszkańskiej, Guilberta (Gilberta) z Tournau (zm. 1288) ${ }^{59}$.

Komentarz do Psalmów, trzyczęściowy, w opracowaniu św. Augustyna z załączonym słowniczkiem „Złotych myśli” (Principaliarum sententiarum), wydobytych z psalmów, w edycji bazylejskiej Jana Amerbacha z 1489 r., w formacie folio. Był w posiadaniu biblioteki konwentu stradomskiego, o czym świadczy nota własnościowa ${ }^{60}$.

${ }^{56}$ Biblia. /Strassburg/ 1483 (Kraków Bern. def.); Biblia, cum postllis Nicolai de Lyra... Strassburg 1492. - Incunabula Poloniae nr 1015 i 1046; BPBK Dział Inkunabułów sygn. 462 i 581.

${ }^{57}$ P. de Burgos krytykował Mikołaja de Lyra za hołdowanie egzegezie literalnej Pisma św., natomiast bronil go Maciej Doering w dziele pt. „Defensorium Postillae”. Utarło się nawet krzywdzace Mikołaja powiedzenie: „Si Lyra non lirasset, Lutherus non saltasset”. Nie można bowiem wskazać na jakiekolwiek akcenty nauki Mikołaja de Lyra, które byłyby specyficznie luterskie. Wprost przeciwnie Mikołaj był wyraźnie pod wpływem nauki św. Bonawentury i Aleksandra z Hales. - A. K le in h a u s, Nicolaus v. Lyra OFM. W: Lexikon f. Theologie u. Kirche. T. 7. Freiburg am Mein 1962, kol. 992.

${ }_{58}$ M. Z a c hajki e w i c z, Hugon z Saint-Cher (Hugo a S. Caro). W: Encyklopedia Katolicka. T. 6. Lublin 1993, kol. 1291. - Wszystkie trzy części opisuja Incunabula Poloniae pod nr 1041. Sa w posiadaniu BPBK (Dział Inkunabułów) pod sygn. 610.

${ }^{59}$ G. F u s s e n e g g e r, Guibert v. Tournai OFM. W: Lexikon f. Theologie u. Kirche. T. 4. Freiburg am M. 1960, kol. 1266.

${ }^{60}$ Explanatio Psalmorum Aurelii Augustini. Cz. 1-3. Basel 1489. - Por. Incunabula Poloniae nr 645; BPBK Dzial Inkunabułów nr 549. - Nota własnościowa na karcie tytułowej: „Conventus Cracoviensis PP. Bernardinorum" świadczy o przynależności tego egzemplarza do tutejszej biblioteki konwentu krakowskiego. Z kolei późniejsza nota dedykacyjna: „Pro Conventu Pacis Virg/inis/Imm/aculatae/ ad Praesepe Cracoviensis" jest dowodem, iz w w. XVII przekazano pozycję erygowanemu wówczas klasztorowi w Krakowie „Na Żłóbku”, przy ul. Św. Jana. 


\section{Patrystyka}

Dział patrystyczny w bibliotece konwentu stradomskiego, w swoich najwcześniejszych zasobach z końca XV i początków XVI w. przedstawia się nadzwyczaj ubogo. Przewyższaja go zdecydowanie analogiczne zasoby innych bernardyńskich bibliotek klasztornych, a w tym szczególnie sokalskiej, tarnowskiej i w Kalwarii Zebrzydowskiej ${ }^{61}$. Możemy w nich znaleźć dzieła takich ojców zachodnich Kościoła, jak Cyprian z Kortony (zm. 252), Ambroży z Mediolanu (zm. 397), Hieronim ze Strydonu (zm. 419) i Augustyn z Hippony (zm. 430), a nawet Paweł Diakon (zm. 799). Z ojców wschodnich mamy w Krakowie, ale w dziale biblioteki klasztoru w Sokalu, „25 Mów” Jana Chryzostoma. Natomiast w bibliotece konwentu krakowskiego mamy zaledwie cztery inkunabuły patrystyczne. Sa to Pseudo-Hieronima „Żywoty Ojców”, popularne w Niemczech w drugiej połowie XV w., tłoczone w oficynie A. Kobergera w Norymberdze ${ }^{62}$. Następnie „Dzieła” Laktancjusza, pisarza łacińskiego i filozofa z początku IV w., z jego „Bożymi naukami” oraz ich „Streszczeniem”. Ponadto jedyne dzieło św. Augustyna, wspomniane wyżej w dziale komentarzy biblijnych „Wyjaśnienie do Psalmów" "63. Wreszcie z czasów Karola Wielkiego, a więc napisane po okresie Ojców Kościoła, dzieło Pawła Diakona (zm. 799): „Homiliarz doktorów”" ${ }^{\text {"64 }}$, stanowiący wraz z innymi dziełami tegoż autora swego rodzaju pomost między starożytnością chrześcijańska, a wczesnym średniowieczem karolińskim. Autor prawie w całości przejął „homilie i postylle” Ojców Kościoła i pisarzy kościelnych wschodnich i zachodnich. Sam napisał tylko kilka postylli, dołączając listy i wiersze, ze słynnym poematem o św. Janie Chrzcicielu: „Ut queant laxis...”. Wiersz ten posłużył bowiem Gwidonowi z Arezzo do nazwania nut na czterolinii (,ut, re, mi, fa, sol...") $)^{65}$.

Szczupłość działu patrystycznego z drugiej połowy XV w. można w pewnej mierze wytłumaczyć brakiem w całym Kościele u schyłku średniowiecza, większego zainteresowania teologią patrystyczną. Dominowała jeszcze w pełni scholastyka. Wprawdzie już w drugiej połowie XV w. dawały o sobie znać tendencje odrodzeniowe, polegające między innymi na ożywieniu badań nad dziełami Oj-

${ }^{61}$ BPBK. Dział Inkunabułów nr 443 adl. (prowen. Sokal), nr 516 (prowen. Kraków). 544 i 545 (prowen. Tarnów), nr 549 i 617 (prowen. Kraków).

${ }_{62}$ P s e u d o- H i e r o n y m u s, Vitas Patrum. Nürnberg 1478. - BPBK sygn. 617.

${ }^{63}$ Augustinus Aurelius S., Explanatio psalmorum. T. 1-3. Basileae 1489. - Por. Incunabula Poloniae nr 645; BPBK. Dział Inkunabułów sygn. 549.

${ }^{64}$ Paweł Diakon, autor m. in. dzieła: „Historia Longobardorum” (do roku 744) przygotował znany w średniowieczu zbiór homilii pt. Homiliarius Doctorum (Cz. 1-2. Nürnberg 1494). - Krakowski egzemplarz tego dzieła wydany w Bazylei w 1493 r. posiada na karcie tytułowej ilustracje Ojców i pisarzy kościelnych, do których wypowiedzi sięgną Paweł w swoim „Homiliarzu”. Są to: Hieronim, Orygenes, Jan Chryzostom, bp Maksym, pap. Leon Wielki, Augustyn z Hippony, Ambroży, Alkuin, Beda Czcigodny i pap. Grzegorz Wielki. - Natomiast inne wydanie tego dziela, z roku 1494, nabył w Krakowie niejaki Marcin Strzambowski (1591?). W pierwszej połowie XVII w. znalazło się w księgozbiorze klasztoru w Sokalu. (Por. BPBK. Dział Inkunabułów nr 233).

${ }^{65}$ J. M. S z y m u s i a k, M. S t a r o w i e y s k i, Stownik wczesnochrześcijańskiego piśmiennictwa, Poznań 1971, s. 320. 
ców i coraz częstsze wydobywanie tekstów źródłowych chrzescijaństwa, a zwłaszcza Biblii i dzieł patrystycznych ${ }^{66}$.

Do innych przyczyn uszczuplania biblioteki konwenckiej na Stradomiu w zakresie dzieł patrystycznych można zapewne zaliczyć fakt przekazywania przez prowincjałów niektórych pozycji krakowskich, bibliotekom nowopowstających konwentów. Już bowiem w czasach pobytu Jana Kapistrana w Europie wschodniej, a więc w pierwszych latach istnienia konwentu krakowskiego św. Bernardyna ze Sieny, przekazano około1460 r. rękopiśmienną księgę kazań pasyjnych autorstwa Kapistrana, dla nowopowstałego klasztoru w Samborze ${ }^{67}$. Czynił to również prowincjał Krzysztof Scipio del Campo w XVII w. na rzecz nowego domu zakonnego „Na Żłóbku” w Krakowie ${ }^{68}$. Te dwa przykłady wydają się potwierdzać hipotezę, iż czynili podobnie inni prowincjałowie, korzystając z prawa dysponowania księgami po zmarłych zakonnikach, według własnego uznania. Przekazywali je najczęściej dla bibliotek studiów zakonnych filozofii i teologii ${ }^{69}$. Prowincjałowie oraz komisarze generalni byli tym szczególnie zainteresowani, gdyż regularnie odbywali wizytacje klasztorów i z urzędu wspomagali konwenty studiów zakonnych.

\section{Teologia scholastyczna (wybrane inkunabuly)}

W tym dziale na pierwszy plan w kolejności chronologicznej druków wysuwa się "Teologia powszechna" Rainera Giordaniego z Pizy, dominikanina (zm. 1348) stanowiąca najstarszy słownik podstawowych tematów teologicznych ułożonych alfabetycznie. Wydano je w dwu częściach - w 1473 r. Autor był znany jako XIV-wieczny zagorzały tomista, choć w swojej „Pantheologii” cytuje również innych mało znanych autorów ${ }^{70}$. Jako opracowanie encyklopedyczne dyscyplin teologicznych i prawa kanonicznego, dzieło Giordaniego z Pizy przybliżało wiedzę teologiczną zawartą w monumentalnych opracowaniach wielkich scholastyków (św. Tomasza, bł. Jana Dunsa Scota) i było aktualne w następnym ćwierćwieczu mimo ukazania się w 1517 r. „Słownika teologii” Jana Altensteina oraz innych podobnych leksykonów teologii. Mamy też w bibliotece bernardyńskiej w Krakowie "Małą Sumę" Rajmunda z Penafort generała zakonu Dominikanów i wielkiego misjonarza mahometan; przede wszystkim zaś „Sumę teologiczną" największego teologa średniowiecza, św. Tomasza z Akwinu, druko-

${ }^{66}$ Ośrodkami tego ruchu wydawniczego stały się w drugiej połowie XV w. m. in.: Bazylea, Norymberga, Strassburg i Wenecja.

${ }^{67}$ L. W a d d i n g, Annales Minorum. T. 12. Quaracchi 1932, s. 484, (420) nr 125.

${ }^{68}$ Dzieło św. Augustyna „Explanatio Psalmorum” (Cz. 1-3. Basileae 1489. - Por. Incunabula Poloniae nr 645 oraz BPBK. Dział Inkunabułów sygn. 549). Egzemplarz bernardyński posiada dwie noty proweniencyjne: jedna należy do biblioteki konwentu na Stradomiu w Krakowie, a druga - z wieku XVII - do klasztoru „Ad Pacem”, podpisana przez Krzysztofa Scipio del Campo.

${ }^{69}$ Bardzo liczne noty własnościowe $\mathrm{z}$ podpisem prowincjała Benedykta Gąsiorka na ksiązkach przekazanych na pocz. XVII w. bibliotece studium zakonnego w Samborze, wydają się również świadczyć o tego rodzaju uszczuplaniu bibliotek wielkich konwentów na rzecz słabszych, w których było studium zakonne.

${ }^{70}$ A. W a $1 \mathrm{t}$ z, Reiner Giordani v. Pisa. W: Lexikonf. Theologie u. Kirche, T. 8, kol. 980. 
waną w Bazylei ok. 1477 roku $^{71}$. Nie brak też w grupie kompendiów teologii „Streszczenia prawdy teologicznej” Pseudo-Alberta Wielkiego, tłoczonego w Strassburgu u J. Prüssa w 1489 roku $^{72}$.

Wśród inkunabułów omawianego działu teologii scholastycznej nie ma w naszej bibliotece dzieł scholastyków starej szkoły franciszkańskiej ${ }^{73} \mathrm{z}$ wyjątkiem komentarza św. Bonawentury do „Sentencji” Piotra Lombarda, wydawanego w 1491 i 1500 roku $^{74}$. Z tego też czasu pochodzi druk dzieł św. Anzelma z Canterbury (zm. 1109), wykonany w Norymberdze w 1491 roku u C. Hochfedera, a w szczególności zawarte w nich opracowania ściśle teologiczne „O Wcieleniu Słowa”, „O poczęciu dziewiczym Chrystusa” i „O grzechu pierworodnym”, „O pochodzeniu Ducha Świętego od Ojca i Syna” oraz „Monoligium” o nieśmiertelności duszy ludzkiej. Anzelm starał się w swoich opracowaniach wyjaśnić rozumowo prawdy objawione, w związku z czym w konstruowaniu argumentacji posługiwał się filozofią jako nauką pomocniczą teologii. W bernardyńskim zbiorze „Dzieł” Anzelma są również niektóre traktaty ascetycznomistyczne, całość bowiem została ujęta jako „teologia kompletna”, bez wydzielania poszczególnych jej dyscyplin. Brakuje natomiast znanych skądinąd jego opracowań mariologicznych, jak „Hymny i Psalmy o Najświętszej Maryi Pannie” i „Modlitwy” określające Matkę Zbawiciela jako „Matkę miłosierdzia”, „Matkę naszą", a szczególnie „Matkę Bożą"75.

Dzieła czołowego teologa franciszkańskiego Jana Dunsa Scota są tu reprezentowane przez „Kwestie na 4. Ksiegi Sentencji” z tekstem Piotra Lombarda, w edycji weneckiej z 1489 roku $^{76}$ oraz wznowienie tychże w osiem lat później przez Filipa Bagnacaballo ${ }^{77}$. Ponadto dwa wydania „Kwestii różnych” (Quaestiones quod libetales) bł. Jana Dunsa Scota z 1490 i 1497 r. oraz kompendium do monumentalnego dzieła Jana Kapreola, napisana przez włoskiego dominikanina Sylwestra Prieriasa, znanego $\mathrm{z}$ początków reformacji jako uczestnik procesu

${ }^{71}$ Thomas de Aqu in o s., Summa theologiae. Secunda secundae. Basileae 1477. Por. BPBK Dział Inkunabułów sygn. 624 /Incunabula Poloniae nie notuja/.

${ }^{72}$ Pseudo-Albertus Magnus, Compendium theologicae veritatis. Cum Tabula Thomae Dorniberg. Strassburg 1489. - Por. Incunabula Poloniae nr 142 oraz BPBK. Dział Inkunabułów sygn. 394 adl.

${ }^{73}$ Dzieła św. Bonawentury i Aleksandra z Hales mamy w rękopisie bibliotecznym. - Por. BPBK sygn. $1 / \mathrm{R}$ adl.

${ }^{74} \mathrm{P}$. L o m b a rdu s, Sententiarum libri IV cum commentario s. Bonaventurae. Cz. 1-2. Nürnberg 1491; Toż. 1500. - Por. Incunabula Poloniae nr 4338 oraz nr 4340; BPBK. Dział Inkunabułów sygn. 569 i 573.

${ }^{75}$ M. Z i o ł k o w s k i, Anzelm z Canterbury. W: Encyklopedia Katolicka. T. 1. Lublin 1973, kol. 735.

${ }^{76}$ Oba wydania ukazały się w Wenecji w oficynach wydawniczych B. Rizusa i B. Lokatella w 1489 i 1497 r. - Por. Incunabula Poloniae nr 4344 i 1997 oraz BPBK. Dział Inkunabułów sygn. 554 adl., 556 adl. i 558.

${ }^{77}$ Por. Incunabula Poloniae nr 1991 i 1992; BPBK. Dział Inkunabułów sygn. 555 adl., 557 adl., 559 adl. 
rzymskiego przeciw Marcinowi Lutrowi i zagorzały działacz opozycji antyreformacyjnej $^{98}$.

Do rzadkich druków w bibliotece klasztornej należało niewątpliwie dzieło pt. "Scot ubogich" (Scotus pauperum), tłoczone w Spirze w 1492 r. u Piotra Dracha $^{79}$. Z tej samej drukarni wyszły rok wcześniej „Sentencje” Piotra z Lombardii z komentarzem św. Bonawentury, których dwie pierwsze księgi znajdujemy w krakowskiej bibliotece Braci Mniejszych ${ }^{80}$.

${ }^{78}$ Silvester de P r i e r i o (Prierias) OP, Compendium in opus Joannis Capreoli in $\mathrm{V} V$. libros Sententiarum, cum additionibus. Cremona 1497. - Por. Incunabula Poloniae nr 5040; BPBK. Dział Inkunabułów sygn. 240.

${ }^{79}$ G. G erris, Scotus pauperum. Speier ok. 1492. - Por. Incunabula Poloniae nr 2420; BPBK. Dział Inkunabułów sygn. 57 adl.

${ }^{80}$ Por. Incunabula Poloniae nr 4338; BPBK. Dział Inkunabułów sygn. 573. 